\title{
Perilaku komunikasi santri Kota Tangerang terkait informasi pornografi melalui Internet
}

\author{
Inge Hutagalung \\ Universitas Mercu Buana, Jakarta, Indonesia
}

\begin{abstract}
ABSTRAK
Penelitian terkait selective exposure terkait pornografi pada remaja DKI Jakarta telah dilakukan pada tahun 2012. Hasil penelitian menunjukkan kegunaan informasi berpengaruh kuat dibandingkan variabel dukungan kelompok dan keyakinan (belief) terhadap selective exposure. Adapun variabel keyakinan (belief) memiliki pengaruh yang paling lemah terhadap selective exposure. Hasil penelitian model teoritik yang telah dilakukan di kalangan remaja DKI Jakarta ini menimbulkan pertanyaan bagaimana jika pengujian model teoritik ini dilakukan di kalangan remaja pesantren. Hal ini menarik diteliti mengingat pola asuh di pesantren memiliki model pengasuhan yang tunduk pada pengasuh pesantren. Dalam penelitian ini uji hipotesis dilakukan dengan teknik analisis multivariat. Metode pengambilan sampel menggunakan sampel acak klaster (cluster random sampling). Hasil penelitian terkait selective exposure tentang pornografi para santri di kota Tangerang, menunjukkan bahwa dukungan kelompok sangat berpengaruh terhadap pilihan informasi pornografi secara langsung. Responden pria menyatakan pornografi memiliki kegunaan informasi, dan sebaliknya pada responden perempuan. Responden tergolong sensitif terhadap pornografi dan memiliki keyakinan negatif. Lebih lanjut, hasil penelitian menunjukkan adanya kepentingan terhadap informasi pornografi terkait edukasi seks, namun informasi tersebut tidak berpengaruh untuk menjadi petunjuk bagi kegiatan seksual.
\end{abstract}

Kata-kata Kunci: Selective exposure; pornografi; keyakinan; dukungan kelompok; pesantren

\section{Communication of santri in Tangerang related with pornographic information through the Internet}

\begin{abstract}
In 2012, a study on selective exposure to pornographic information via the internet among Jakarta adolescents was carried out in a model. The results showed that based on the theoretical model tested, it was found that the information usefulness variable had a more substantial influence than the group support and belief variables on selective exposure, and belief variable is the weakest. The results of this theoretical model research that has been carried out among adolescents in DKI Jakarta raise the question of what if the testing of this theoretical model is carried out among pesantren adolescents. This research is an exciting study considering that pesantren's parenting style model is subjected to the pesantren's caregiver. Hypothesis testing is done by using multivariate analysis techniques. The sampling method used was random cluster sampling. The research results related to the selective exposure model of pornography via the internet among pesantren adolescents conducted in Tangerang city show that group support dramatically influences the choice of direct pornographic information. Male respondents stated that pornography has information uses, and vice versa for female respondents. Respondents are classified as sensitive to pornography and have opposing beliefs. Furthermore, the study results indicated that there was an interest in pornographic information related to sex education, but this information did not have the effect of being an indication of sexual activity.
\end{abstract}

Keywords: Selective exposure; pornography; belief; group support; boarding school

Korespondensi: Dr. Inge Hutagalung M.Si, Program Magister Ilmu Komunikasi Universitas Mercu Buana, Jl. Meruya Selatan No.1, Kembangan - Jakarta Barat 11650. Email: inge_hutagalung@yahoo.com. inge_ hutagalung@mercubuana.ac.id. 


\section{PENDAHULUAN}

Pornografi telah melanda Indonesia dan menempatkan Jakarta di posisi keempat sebagai ibukota pengakses kata "sex" pada pencari internet, dengan pengakses materi terbanyak adalah para pelajar (Hutagalung, 2018; Kholisoh, 2018). Pornografi adalah masalah sosial yang berdampak negatif tidak hanya pada kesehatan namun juga merupakan masalah kejiwaan terkait mental.

Perkembangan informasi dan teknologi juga telah membuat khalayak menjadi lebih aktif dalam melakukan pengolahan informasi yang ada dalam kehidupan. Khalayak akan melakukan proses pemilihan informasi sesuai dengan minat dan kebutuhan. Informasi yang dirasakan memiliki manfaat akan dipilih, dan sebaliknya (Bennett \& Iyengar, 2008).

Perubahan pola pengolahan informasi ini telah menempatkan khalayak sebagian penentu aktif terhadap pemilihan informasi. Terkait dengan kondisi ini akan menarik bila dilakukan penelitian terkait faktor apa saja yang berperan mempengaruhiperilakupemilihandanpenolakan informasi (selective exposure) tersebut? Hal ini menarik untuk dipertanyakan mengingat proses pengolahan informasi yang dilakukan individu dipengaruhi oleh faktor internal dan eksternal diri. Sebagai mahluk sosial, khalayak dalam memilih ataupun menolak informasi tidak saja berdasarkan manfaat namun juga dipengaruhi nilai dan norma yang berlaku dalam kehidupan masyarakat.

Hipotesis selective exposure menempatkan kondisi psikologis sebagai penyebab seseorang memilih dan menghindari informasi. Hipotesa ini telah menempatkan individu sebagai pemroses informasi aktif yang secara internal mempunyai kekuatan dan kemampuan untuk memilih dan menolak informasi dalam upaya mencapai keselarasan kognisi (Festinger, 1957). Kondisi ini terkesan selaras dengan posisi teori disonansi kognitif (sebagai sumber konsep selective exposure) yang dikenal sebagai teori yang bersifat individual, di mana proses timbulnya disonansi maupun aplikasinya diasumsikan terjadi melalui proses mental secara pribadi (Littlejohn \& Foss, 2011).

Jika Festinger lebih menitikberatkan pada aspek psikologis (belief), maka serangkaian penelitian yang dilakukan para ahli pasca penelitian Festinger membuktikan adanya aspek lain yang memiliki pengaruh pada selective exposure, yaitu aspek pesan maupun sosial. Perilaku untuk memilih maupun menolak informasi bukan hanya disebabkan oleh aspek psikologis semata tetapi juga aspek pesan dan sosial.

Dengan kata lain, pemilihan dan penolakan informasi yang dilakukan individu dapat dilandasi oleh maksud-maksud lain, dan tidak hanya terbatas pada maksud untuk menciptakan konsonansi antara sikap dengan keyakinan (belief) ataupun antara sikap dengan perilaku. Di sisi lain, dipahami bahwa selama ini para peneliti melakukan kajian untuk membuktikan bahwa penyebab selective exposure dapat disebabkan oleh berbagai faktor selain variabel keyakinan (belief).

Menyadari bahwa kajian penyebab selective exposure selama ini belum mencapai kebulatan suara (unanimity), dan cenderung hanya fokus pada satu variabel ataupun satu aspek serta memahami perilaku komunikasi melibatkan berbagai aspek (Fischer \& Greitemeyer, 2010. Maka pada tahun 2012 peneliti telah melakukan penelitian dengan mengintegrasikan tiga aspek kajian selective exposure dalam sebuah model berfokus pada informasi pornografi. Perbedaan penelitian ada pada pengujian tiga variabel dari tiga aspek dalam sebuah model. Hasil penelitian menunjukkan bahwa secara terintegrasi variabel keyakinan (belief), kegunaan informasi dan kelompok berpengaruh terhadap pola pemilihan informasi. Variabel kegunaan memiliki pengaruh yang lebih kuat dibandingkan variabel dukungan kelompok dan keyakinan (belief) terhadap selective exposure. Adapun variabel keyakinan (belief) memiliki pengaruh yang paling lemah terhadap selective exposure.

Hasil penelitian model teoritik yang telah dilakukan di kalangan remaja DKI Jakarta ini menimbulkan pertanyaan bagaimana jika pengujian model teoritik selective exposure dilakukan di kalangan remaja pesantren. Apakah variabel kegunaan informasi akan memiliki pengaruh yang paling kuat? Apakah variabel keyakinan (belief) akan memiliki pengaruh yang paling lemah? Hal ini menarik untuk diteliti mengingat pola asuh di pesantren memiliki model pengasuhan yang tunduk pada pengasuh pesantren.

Selective exposure secara sederhana dapat didefinisikan sebagai upaya individu untuk 
menseleksi informasi yang diinginkan dan tidak diinginkan. Ketersediaan informasi sangatlah banyak, dan individu akan menseleksi dan memilih informasi yang akan diakses dan tidak diakses (Fischer et al., 2011). Ditemukannya fenomena selective exposure tidak bisa dilepaskan dari perjalanan panjang penelitian dampak media massa. Penelitian komunikasi massa hingga sekitar tahun 1950-an memiliki kecenderungan untuk lebih memerhatikan dampak media pada audien, yaitu bagaimana media memengaruhi audien dan dampak media pada perilaku mereka. Dalam pemanfaatan media maupun informasi, individu kerap diasumsikan pasif menerima informasi daripada bersikap aktif mencari, memilih dan menyaring informasi yang ada. Seiring dengan perjalanan waktu, para ahli teori menyadari bahwa audien memiliki resistensi (penolakan) terhadap informasi. Saat itu, walaupun sadar bahwa audien melakukan proses seleksi terhadap informasi namun terminologi selective exposure belum dikenal. Di sisi lain, sedikit sekali perhatian yang diberikan para ahli terhadap fenomena pemilihan dan penolakan media maupun informasi yang dilakukan oleh individu (Baran, 2012). Baru setelah penjelasan Festinger melalui teori disonansi kognitif, terminologi terkait pemilihan dan penolakan media maupun informasi yang dilakukan oleh individu dikenal sebagai selective exposure (Festinger, 1957).

Adalah Leon Festinger yang memperkenalkan selective exposure dari perspektif teori disonansi kognitif. Menurut Festinger, individu sebagai pencari konsistensi kognitif akan menjaga kemapanan dan konsistensi dalam kognitif berdasarkan keyakinan (belief) (Festinger, 1957). Seiring perjalanan waktu, banyak kajian yang telah dilakukan menunjukkan bahwa perilaku pemilihan dan penolakan informasi (selective exposure) tidaklah hanya berhubungan dengan aspek psikologis (keyakinan) semata, namun juga dapat dipengaruhi oleh aspek di luar aspek psikologis. Dalam sebuah ringkasan penelitian disimpulkan bahwa hanya ada sedikit bukti untuk mendukung hipotesis bahwa seseorang akan menolak informasi-pemicu disonansi. Manfaat informasi dapat mendorong seseorang untuk memerhatikan informasipemicu disonansi. Informasi kontradiktif yang baru, menarik, penting, relevan secara pribadi, atau menghibur mungkin tidak akan ditolak. Informasi kontradiktif yang bermanfaat dalam pembelajaran suatu ketrampilan atau pemecahan masalah mungkin akan diperhatikan. Dengan kata lain, apabila sebuah informasi ataupun pesan berisi penghargaan yang jauh melampaui ketidaknyamanan psikologis atau disonansi yang ditimbulkan, maka kecenderungan informasi/pesan kontradiktif tersebut tidak akan ditolak.

Dengan kata lain, pemilihan dan penolakan informasi yang dilakukan individu dapat dilandasi oleh maksud-maksud lain, dan tidak hanya terbatas pada maksud untuk menciptakan konsonansi antara sikap dengan keyakinan (belief) ataupun antara sikap dengan perilaku. Ada unsur lain di luar variabel keyakinan (belief) yang dapat menyebabkan selective exposure.

Perkembangan pasca penelitian Festinger menunjukkan bahwa faktor psikologis, pesan dan sosial bisa mempengaruhi perilaku selective exposure. Sebagai mahluk sosial, aspek sosial berpengaruh pada pemilihan dan penolakan informasi dikarenakan nilai dan norma masyarakat. Keyakinan (belief) yang dimiliki individu seperti komitmen, suasana hati juga memiliki pengaruh pada proses seleksi informasi. Sementara itu, informasi yang memiliki manfaat terhadap kebutuhan individu juga memiliki pengaruh terhadap pola pemilihan informasi (Hutagalung, 2017).

Salah satu aspek yang mempengaruhi selective exposure adalah kegunaan informasi. Adalah Atkin yang menekankan pentingnya kegunaan sebagai dasar seseorang dalam memilih dan menghindari suatu informasi. Atkin menolak pandangan Festinger yang menyatakan selective exposure dilakukan untuk mengurangi disonansi seseorang (Zillmann \& Bryant, 1985). Selective exposure sebaliknya dilakukan oleh individu untuk memenuhi kegunaan akan informasi. Atkin menitikberatkan pada "threats and opportunities" sebagai dua hal yang saling berkaitan. Jadi informasi yang dipilih tidak harus informasi yang sesuai dengan sikap dan keyakinan, tetapi juga informasi yang bertentangan asalkan informasi tersebut bisa memenuhi kegunaan individu akan informasi. Yakni kegunaan akan petunjuk, penguatan sikap dan bagaimana melakukan sesuatu.

Lebih lanjut, Atkin menyatakan bahwa seseorang juga mungkin memilih informasi 
negatif (disonan), asalkan informasi tersebut memiliki kegunaan informasi. Sebagai misal, Indonesia saat ini tengah mengembangkan Pembangkit Listrik Tenaga Nuklir (PLTN). PLTN selama ini dipromosikan sebagai alternatif energi yang aman dan murah. Pada saat bersamaan terjadi ledakan reaktor nuklir Fukushima di Jepang akibat gempa tsunami. Jika mengikuti Festinger, orang Indonesia (terutama di Bangka Belitung sebagai tempat akan dibangunnya PLTN) cenderung untuk menghindari informasi yang negatif, informasi yang bisa mengakibatkan timbulnya rasa ketidaknyamanan (disonansi). Disonansi itu terjadi karena Jepang sebagai negara maju saja tidak bisa menangani kebocoran PLTN, apalagi Indonesia yang tidak menguasai teknologi. Untuk mengurangi disonansi, orang akan menghindari (avoidance) informasi mengenai PLTN Fukushima, dan lebih memilih informasi tentang PLTN yang aman, misalnya keberhasilan Iran dalam mengembangkan PLTN. Tetapi jika mengikuti pendapat Atkin, orang juga akan memilih informasi mengenai PLTN Fukushima. Meskipun negatif dan menimbulkan ketidanyamanan psikologis, informasi mengenai PLTN Fukushima ini memenuhi kegunaan seseorang akan infomasi, akan "threat" yang bisa dipakai untuk surveillance situasi, bertindak dan menilai sesuatu.

Penelitian Knobloch telah mengembangkan gagasan Atkin. Menurut mereka, selective exposure dilakukan untuk memenuhi kegunaan seseorang akan informasi. Seleksi itu tidak ditentukan oleh apakah informasi itu sesuai atau tidak sesuai dengan disonansi seseorang, tetapi lebih karena kegunaan sebuah informasi. Kegunaan itu akan meningkat ditentukan oleh tiga faktor. Pertama, persepsi terhadap besarnya (magnitude) suatu peristiwa atau kasus (Knobloch-Westerwick, 2012). Peristiwa yang besar dan berkaitan langsung dengan kehidupan seseorang akan lebih mungkin dipilih. Ilustrasi mengenai kebocoran PLTN Fukushima di atas memenuhi kategori ini. Meski negatif, informasi mengenai PLTN Fukushima itu mempunyai relevansi magnitude karena Indonesia hendak membangun PLTN di Bangka Belitung. Kedua, persepsi tentang kedekatan (proksimitas) baik waktu, tempat ataupun psikologis. Perang di Libya secara teoritis, meski tidak menyenangkan dan negatif akan dipilih karena kedekatan emosional bagi sebagian besar mayoritas masyarakat Indonesia yang beragama Islam. Ketiga, persepsi tentang keterkaitan peristiwa dengan kehidupan seseorang secara langsung. Peristiwa gempa tsunami di Jepang, meskipun tidak menyenangkan, akan lebih dipilih dan diakses oleh masyarakat yang berada di daerah rawan gempa (seperti daerah yang berada di pesisir pantai) dibandingkan dengan orang yang tinggal di wilayah yang tidak berpotensi gempa.

Hasil penelitian terurai di atas juga membuktikan bahwa orang dalam melakukan selective exposure akan memerhatikan dan memilih informasi yang bermanfaat sekalipun informasi termaksud bertentangan dengan keyakinan (belief). Kegunaan informasi ini dipahami sebagai seberapa jauh sebuah informasi yang tersedia dapat digunakan untuk memudahkan pembuatan keputusan-keputusan secara tepat.

Sementara itu, dalam penelitiannya, Galdi menjelaskan bahwa pola pemilihan informasi juga dipengaruhi oleh nilai dan norma kelompok. Dorongan untuk berkomunikasi tentang suatu hal dengan anggota lain dalam kelompok akan meningkat manakala disadari terdapat ketidaksetujuan dengan hal yang dikomunikasikan. Peningkatan ini terjadi apabila hal yang dibicarakan adalah penting dan sifat keterikatan individu dengan kelompok adalah erat. Sebagai anggota suatu kelompok, orang lebih cenderung mengarahkan komunikasinya tentang suatu hal kepada mereka yang kelihatannya memiliki kesamaan pemikiran/ persetujuan. Dan sebaliknya, cenderung untuk mengurangi komunikasi dengan mereka yang terlihat memiliki pertentangan pendapat. Di sisi lain, dorongan untuk tetap menjadi bagian kelompok akan memengaruhi perubahan suatu pendapat ataupun keyakinan (belief). Semakin erat dorongan untuk tetap menjadi bagian kelompok, maka akan semakin besar perubahan pendapat dilakukan. Hal ini merupakan upaya penyesuaian diri agar tetap berada dalam kelompok (Galdi et al., 2012).

Sebagaimana telah dijelaskan sebelumnya, Festinger menegaskan bahwa dukungan sosial (social support) merupakan sumber disonansi kognitif seseorang, dan sekaligus juga merupakan sarana utama untuk mengeliminasi serta menurunkan disonansi. Yaitu, bahwa individu akan merubah keyakinan (belief) manakala bertentangan dengan kelompok untuk 
mencapai keseimbangan kognitif (Festinger, 1957).

Lebih lanjut, penelitian Hutagalung membuktikan bahwa dukungan kelompok dapat menentukan selective exposure. Yaitu berkaitan dengan dukungan kelompok (group support) terhadap pendapat seseorang, yang selanjutnya berdampak pada keinginan untuk membuka diri pada informasi yang bertentangan. Simpulan penelitian Hutagalung menyatakan bahwa semakin kecil perbedaan pendapat orang dengan teman dekat (higher primary group support) maka akan semakin besar kesediaan untuk membuka diri terhadap terpaan informasi yang bertentangan, dan akan semakin besar penolakan terhadap upaya perubahan tingkah laku. Selanjutnya, semakin besar perbedaan pendapat seseorang dengan pendapat secara umum (lower secondary group support), maka semakin besar pula kesediaan untuk membuka diri pada informasi yang bertentangan, dan semakin terbuka terhadap upaya perubahan tingkah laku (Hutagalung, 2018).

Sementara itu, penelitian Knobloch juga menyatakan bahwa dukungan kelompok memiliki pengaruh kuat pada perilaku seseorang. Dukungan kelompok ini merujuk kepada apakah perilaku seseorang sama ataukah berbeda dengan kelompok sosial. Dalam fenomena selective exposure, ini berarti bahwa besar atau kecilnya dukungan dari kelompok (primer maupun sekunder) akan memengaruhi kesediaan seseorang untuk menerima informasi yang bertentangan, atau sebaliknya hanya memilih informasi konsonan. Yaitu, pilihan seseorang pada suatu media maupun informasi akan sangat tergantung pada kuat atau tidaknya perolehan dukungan dari kelompok sosial dimana seseorang menjadi anggota/bagian (Knobloch-Westerwick \& Hastall, 2010).

Penelitian Dohyun menguraikan bahwa kebutuhan akan dukungan kelompok terbagi atas dua aspek yang saling bertentangan. Ada orang yang lebih berorientasi kepada keterkaitan (relatedness) dengan kelompok sosialnya. Orang semacam ini lebih menempatkan orang lain atau kelompok sosial sebagai kesatuan dalam menciptakan kerjasama, simpati, toleransi dan sebagainya. Orang lain dilihat sebagai kesatuan yang menyatu dengan dirinya dalam membentuk komunitas yang padu. Di sisi lain, ada orang yang membutuhkan kelompok sosial untuk membedakan dirinya dengan orang lain (distinctiveness). Konsep mengenai status sosial bersumber dari aspek ini. Dengan kehadiran kelompok sosial, seseorang bisa membedakan status sosial dirinya dengan orang lain. Seseorang bisa menyebut dirinya mempunyai status sosial tinggi jikalau ada orang lain dari kelompok sosial yang mempunyai status sosial yang berbeda, dalam hal ini rendah (Ahn, 2010).

Salah satu teori yang membahas pengaruh kelompok pada perilaku individu adalah teori identitas sosial (social identity theory). Menurut teori identitas sosial individu disadari atau tidak mendapatkan pengaruh dari kelompok/ lingkungan yang menyebabkan dalam konteks sosial yang berbeda individu akan berpikir dan bertindak sesuai dengan aturan kelompok/ lingkungan. Lebih lanjut, pengaruh kelompok yang dijadikan patokan dalam berperilaku akan menimbulkan normative belief. Yaitu, keyakinan dari individu bahwa jika aturan dari kelompok dilanggarkan akan menimbulkan sanksi yang dapat berupa moral ataupun hukum (Griffin, 2011).

Berdasarkan pemikiran teoritik dan penelusuran empirik, terlihat bahwa penjelasan terkait penyebab selective exposure tidak dapat hanya dijelaskan berdasarkan pengaruh satu variabel saja (faktor keyakinan/belief), terbukti bahwa aspek pesan maupun sosial juga dapat menyebabkan selective exposure. Model teoritik yang diajukan dalam penelitian ini mengkaitkan pengaruh variabel keyakinan (belief), kegunaan informasi dan dukungan kelompok terhadap selective exposure. Model ini mempunyai dua kelebihan. Pertama, memasukkan penyebab selective exposure yang terdiri dari tiga variabel dari tiga aspek berbeda, yaitu keyakinan (belief), kegunaan informasi dan dukungan kelompok. Selama ini studi-studi mengenai selective exposure cenderung hanya berfokus pada satu aspek saja. Sementara itu, variabel dukungan kelompok jarang diteliti. Kedua, menguji keterkaitan berbagai variabel sekaligus dalam satu model. Jadi bukan hanya menguji beberapa variabel tetapi juga menguji integrasi pengaruh semua variabel dalam satu model yang utuh yang diharapkan bisa menjelaskan penyebab terjadinya selective exposure secara menyeluruh. Hipotesis penelitian adalah sebagai berikut:

H1: Terdapat pengaruh kegunaan informasi terhadap selective exposure.

Menyikapi penelitian awal Festinger, 


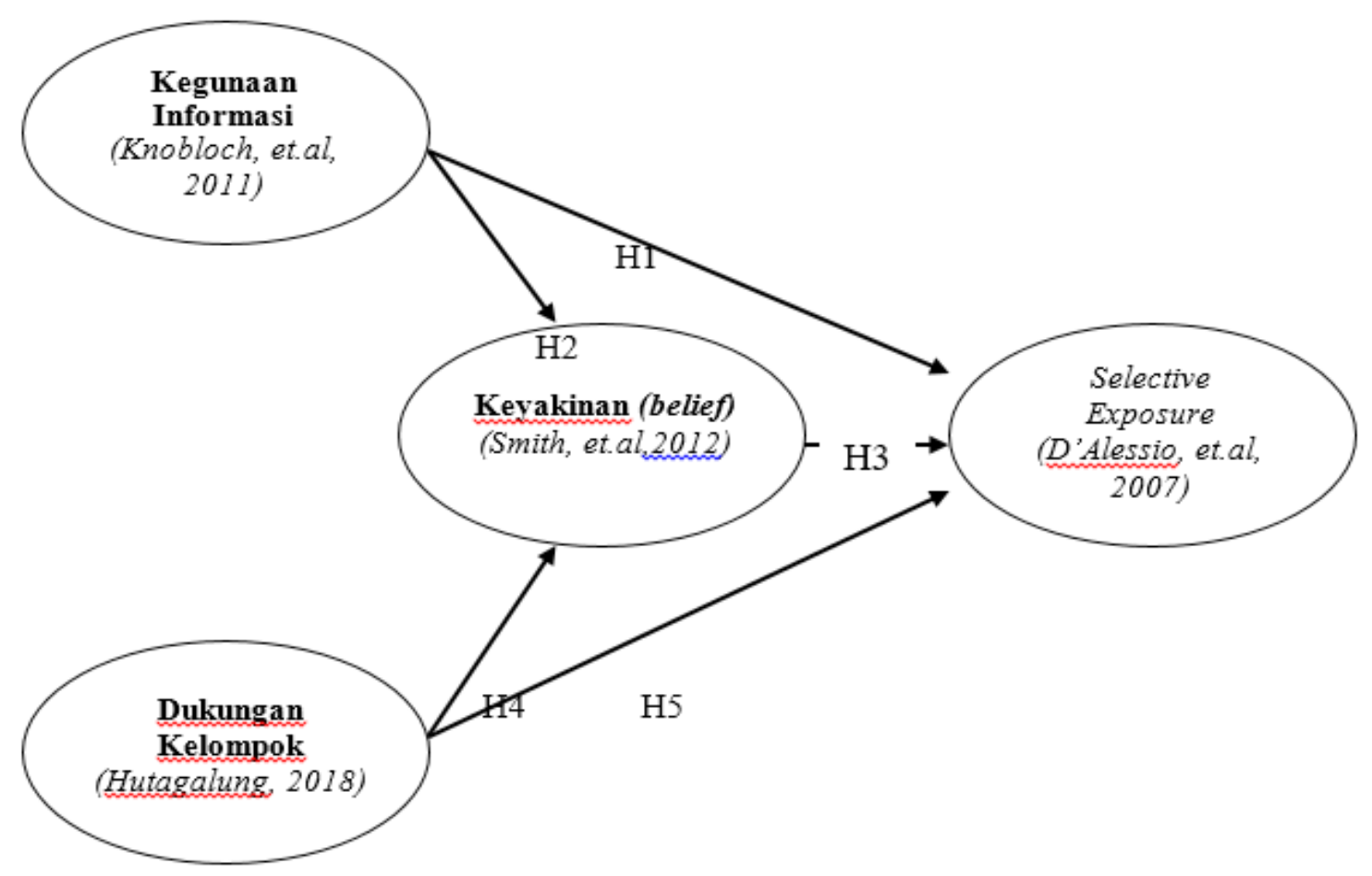

Sumber: penelitian Hutagalung, 2019

Gambar 1 Model Integrasi Pengaruh Variabel Kegunaan Informasi, Keyakinan, dan Dukungan Kelompok terhadap Selective Exposure

mengenai selective exposure yang berakar pada teori disonansi kognitif Festinger. Atkin berpendapat bahwa penelitian tersebut hanyalah menegaskan bahwa informasi yang disonan memiliki kecenderungan untuk ditolak dan dihindari sejalan dengan upaya untuk menurunkan disonansi. Fokus dari hipotesa Festinger adalah menghindari informasi disonan, dan tidak memerhatikan serta mengabaikan pertimbangan kegunaan informasi. Lebih lanjut dijelaskan Atkin, bahwa kebutuhan untuk mempertahankan sebuah keyakinan akan menghasilkan perilaku selektif informasi yang spesifik (Zillmann \& Bryant, 1985). Sementara itu, Atkin juga menegaskan bahwa informasi akan memiliki manfaat terhadap individu tergantung kebutuhan individu terhadap informasi itu sendiri. Apa tujuan dari individu terhadap informasi? Apakah untuk mencari pembenaran dari sebuah keyakinan (belief), ataukah untuk mempelajari sisi negatif dari sebuah informasi? Hal ini perlu dipahami mengingat informasi bisa menjadi ancaman ataupun kesempatan (threats and opportunities) berdasarkan manfaat yang dimiliki.

Dalam kasus pornografi, bisa saja terjadi informasi tentang pornografi dipilih remaja karena dinilai memiliki kegunaan informasi. Remaja, seiring perkembangan biologis dan psikologis (pubertas) cenderung membutuhkan informasi terkait seks dan seksualitas. Di sisi lain, kondisi sebagian besar masyarakat masih menabukan informasi maupun pendidikan seks. Hal ini membuat media pornografi menjadi sumber pembelajaran utama bagi remaja dalam hal mendapatkan pengetahuan mengenai seks dan seksualitas. Dikarenakan kesulitan untuk mendapatkan informasi mengenai seks dan seksualitas melalui jalur formal (lingkungan sekolah, petugas kesehatan) ataupun orang tua, maka remaja cenderung untuk mencari sendiri informasi dimaksud melalui sumbersumber informal (VCD, Internet, buku stensil, film-film porno dan sebagainya). Dalam hal ini, kebutuhan akan informasi tentang seks telah menjadikan informasi tentang pornografi cenderung dipandang memiliki manfaat yang tinggi dan banyak dicari dan dipilih oleh sebagian besar kalangan remaja.

Dengan kata lain, semakin bermanfaat sebuah informasi maka akan semakin dipilih dan dicari. Dan sebaliknya, semakin kurang 
bermanfaat sebuah informasi maka akan semakin ditolak dan dihindari.

H2: Terdapat pengaruh kegunaan informasi terhadap keyakinan (belief).

Kegunaan informasi memiliki pengaruh terhadap keyakinan (belief). Yaitu, sebuah informasi bisa bermanfaat untuk memperkuat ataupun memperlemah keyakinan (belief) seseorang. Dalam hal ini, informasi dapat menjadi bahan sanggahan atau argumentasi untuk menyanggah keyakinan yang bertentangan. Sebaliknya, jika sebuah informasi konsonan dianggap tidak bermanfaat (tidak berkualitas) maka informasi akan ditolak karena dianggap dapat melemahkan keyakinan (belief) (Silvia Knobloch-Westerwick, 2012).

Dengan kata lain, semakin berkualitas sebuah informasi yang bertentangan maka akan semakin berpotensi untuk mengancam keberadaan sebuah keyakinan ataupun pandangan diri. Karena itu, harapan akan tersedianya informasi mendukung yang berkualitas akan meningkatkan pilihan terhadap informasi tersebut sebagai suatu cara untuk mempertahankan pendapat. Sebaliknya, semakin rendah kualitas sebuah informasi yang menentang maka akan semakin 'aman' bagi individu untuk memilihnya, karena diasumsikan tidak akan mengancam namun justru akan semakin memperkuat pilihan pendapat yang telah diyakini.

Dalam kasus pornografi, sebuah informasi tentang pornografi akan semakin bermanfaat dan akan memperkuat keyakinan (belief) bahwa pornografi berpotensi merusak moral generasi bangsa manakala informasi memuat hal terkait peningkatan perilaku seks pranikah di kalangan remaja yang memicu kasus kehamilan tidak dikehendaki (KTD), dan tindakan aborsi yang kerap dianggap sebagai sebuah solusi permasalahan KTD. Namun sebaliknya, informasi yang menentang pornografi akan memperlemah keyakinan (belief) apabila informasi tersebut tidak bisa menyajikan data maupun fakta yang memperlihatkan bahwa pornografi itu berpotensi merusak moral generasi bangsa, khususnya remaja.

H3: Terdapat pengaruh keyakinan (belief) terhadap selective exposure.

Disonansi adalah suatu keadaan atau kondisi dimana terdapat perbedaan atau pertentangan sebuah informasi dengan keyakinan, sikap ataupun keputusan yang dimiliki. Situasi tersebut menimbulkan ketidaknyamanan bagi seseorang secara psikologis. Pada titik ini selective exposure terjadi. Yaitu, untuk mengatasi ketidaknyamanan psikologis terkait keyakinan (belief) yang dimiliki dan untuk mempertahankan keyakinan diri, orang akan cenderung mencari informasi yang sesuai dan mendukung keyakinan diri (konsonan), dan menghindari atau menolak informasi yang disonan (tidak sesuai dengan sikap dan keyakinan) (Festinger, 1957).

Dalam kasus pornografi, jika remaja memiliki pandangan bahwa informasi tentang pornografi adalah bertentangan dengan keyakinan (belief) maka bisa jadi informasi tersebut akan ditolak. Dan sebaliknya, jika informasi tentang pornografi dipandang sebagai sebuah informasi yang tidak bertentangan dengan keyakinan (belief), maka ada kemungkinan informasi akan dipilih.

H4: Terdapat pengaruh dukungan kelompok terhadap keyakinan (belief).

Kelompok kerap mengeluarkan peraturan bagi anggotanya. Manakala seseorang bergabung dengan suatu kelompok sosial, maka disadari atau tidak disadari akan muncul pula kesepakatan bersama atas perilaku yang berlaku dalam masyarakat/kelompok sosial tersebut. Kondisi ini menimbulkan disonansi manakala kesepakatan bersama tidak sesuai dengan keyakinan (belief), dan individu memiliki ketergantungan pada kelompok (referent, misalnya keluarga, teman dekat, kelompok acuan) akan mendukungnya untuk berperilaku sesuai norma subyektif, dan hal ini akan menjadi tekanan sosial bagi individu bersangkutan untuk melakukannya. Sebaliknya jika ia percaya orang lain atau kelompok yang cukup berpengaruh terhadapnya tidak mendukung tingkah laku tertentu, maka hal ini akan menyebabkan individu memiliki subjective norm untuk tidak melakukannya (Hutagalung, 2017).

Dalam kasus pornografi, kedekatan remaja dengan peer-group sangatlah tinggi. Hal ini dikarenanya ikatan dalam peer-group seringkali menggantikan ikatan keluarga, peergroup juga merupakan sumber afeksi, simpati dan pengertian, saling berbagi pengalaman, sekaligus sebagai tempat remaja untuk mencapai otonomi dan independensi. Maka tak heran bila remaja mempunyai kecenderungan untuk mengadopsi informasi yang diterima 
dari teman, tanpa memiliki dasar informasi yang signifikan dari sumber yang lebih dapat dipercaya. Informasi dari teman, dalam hal ini terkait perilaku seks pranikah, tak jarang menimbulkan rasa penasaran yang membentuk serangkaian pertanyaan dalam diri remaja. Untuk menjawab pertanyaan itu sekaligus membuktikan kebenaran informasi yang diterima, remaja cenderung melakukan perilaku seks pranikah itu sendiri (Knobloch-Westerwick \& Hastall, 2010).

H5: Terdapat pengaruh dukungan kelompok terhadap selective exposure.

Sejak awal penelitiannya, Festinger telah mengakui pentingnya peranan kelompok terkait kemunculan dan penurunan disonansi. Melalui penelitian pada sekelompok sekte agama di Amerika, Festinger dan rekan (1956) memaparkan bagaimana dorongan untuk berkomunikasi dengan orang lain ataupun anggota lain dalam kelompok akan meningkat untuk menurunkan disonansi. Bagaimana kelompok dapat menjadi sumber dari informasi yang menimbulkan disonansi, ataupun sebaliknya menjadi sumber dari penurunan disonansi. Dalam ha ini Festinger kembali menegaskan dukungan sosial (social support) merupakan sumber disonansi kognitif seseorang, dan sekaligus juga merupakan sarana utama untuk mengeliminasi serta menurunkan disonansi (Festinger, 1957).

Melalui penelitiannya, Dohyun membuat suatu kesimpulan yang menarik yang memperlihatkan pengaruh dukungan kelompok terhadap pilihan seseorang pada isi media (Dohyun, 2010). Menurut Dohyun, dukungan kelompok terbagi atas dua aspek yang saling bertentangan. Ada orang yang lebih berorientasi kepada keterkaitan (relatedness) dengan kelompok sosialnya. Orang semacam ini lebih menempatkan orang lain atau kelompok sosial sebagai kesatuan dalam menciptakan kerjasama, simpati, toleransi dan sebagainya. Orang lain dilihat sebagai kesatuan yang menyatu dengan dirinya dalam membentuk komunitas yang padu. Di sisi lain, ada orang yang membutuhkan kelompok sosial untuk membedakan dirinya dengan orang lain (distinctiveness). Konsep mengenai status sosial bersumber dari aspek ini. Dengan kehadiran kelompok sosial, seseorang bisa membedakan status sosial dirinya dengan orang lain. Seseorang bisa menyebut dirinya mempunyai status sosial tinggi jikalau ada orang lain dari kelompok sosial yang mempunyai status sosial yang berbeda, dalam hal ini rendah.

Hasil penelitian Dohyun memperlihatkan bahwa orang yang cenderung distinktif lebih menyukai tayangan yang berfokus pada dirinya sendiri. Misalnya tayangan suspense, detektif dan sebagainya. Sebaliknya, orang yang mempunyai kecenderungan untuk terkait dengan orang lain cenderung untuk menyukai tayangan dimana di dalamnya ada keterkaitan antara satu orang dengan orang lain seperti tayangan drama (Dohyun, 2010).

Dalam kasus pornografi, bisa terjadi manakala dukungan kelompok terhadap informasi tentang pornografi cenderung lemah maka informasi tersebut tidak akan dicari dan dipilih, dan sebaliknya. Hal ini bisa disebabkan karena adanya sanksi sosial yang akan timbul jika orang melakukan perilaku yang tidak mendapatkan atau sesuai dengan dukungan kelompok, seperti dikucilkan, dicemoohkan ataupun mendapatkan sanksi hukum seperti dipidana.

\section{METODE PENELITIAN}

Paradigma penelitian adalah positivistik atau klasik, yaitu paradigma yang berangkat dari asumsi bahwa ada suatu realitas sosial yang objektif. Penelitian ini mengambil metode survei. Dengan demikian, seleksi informasi diketahui bukan dengan memberikan perlakuan (treatment) tetapi dengan jalan bertanya kepada responden.

Populasi penelitian ini adalah santri di wilayah Kota Tangerang. Santri ini dipilih untuk mewakili remaja. Penelitian ini membatasi remaja pada usia 16 hingga 20 tahun berdasarkan Undang-Undang No.4 tahun 1979 dan Undang-Undang Perburuhan

Jumlah sampel ditentukan oleh tiga aspek. Pertama, keragaman populasi. Besar kecilnya sampel tergantung diantaranya pada derajat keragaman dari populasi. Populasi yang kompleks dan beragam dari suatu populasi akan semakin membutuhkan jumlah sampel yang besar pula. Pada penelitian ini, keragaman populasi yang dipilih adalah 0,5 (atau proporsi 50\%:50\%). Kedua, tingkat kesalahan yang diinginkan (sampling error). Pada penelitian ini, sampling error adalah 5\%. Ketiga, tingkat kepercayaan. Tingkatkepercayaan berhubungan dengan seberapa besar taksiran atau estimasi 
dari sampel berlaku untuk populasi. Pada penelitian ini, tingkat kepercayaan yang dipilih oleh peneliti adalah 95\%. Lebih lanjut, untuk menentukan jumlah sampel maka keragaman populasi, sampling error dan tingkat kepercayaan dihitung menggunakan software menghasilkan jumlah responden sebesar 200 orang.

Populasi yang terdiri dari seluruh santri yang ada di Kota Tangerang, tidak mungkin semua diwawancarai, sehingga harus ditarik sampel. Untuk menjamin keterwakilan dari populasi maka dilakukan penarikan sampel secara acak klaster. Pada langkah awal ditentukan bentuk klaster, setelah itu dilakukan pengambilan sampel santri. Teknik penarikan sampel ini diambil karena tidak ada kerangka sampel berupa daftar santri di seluruh Kota Tangerang. Tetapi santri tergabung ke dalam klaster yang bernama pesantren, dan ada daftar nama-nama pesantren di seluruh Kota Jakarta. Karena itu, peneliti bisa mengambil terlebih dahulu klaster pesantren, setelah itu baru diambil sampel santri.

Adapun pengujian hipotesis penelitian dilakukan analisis multivariat secara deskriptif maupun inferensial. Untuk pengujian model dilakukan melalui model measurement dan model structural. Melalui pengujian model pengukuran akan dilihat hubungan variabel manifest dan variabel laten. Sementara melalui pengujian model struktural akan dilihat hubungan antara variabel laten.

\section{HASIL DAN PEMBAHASAN}

Untuk variabel kegunaan informasi, semua indikator mempunyai critical ratio (CR) skewness dan kurtosis yang lebih kecil dari ambang batas $\pm 2,58$ pada taraf signifikansi $1 \%$. Dengan demikian bisa disimpulkan bahwa untuk variabel kegunaan informasi, data berdistribusi normal. Data telah memenuhi syarat normalitas data. Variabel dukungan kelompok juga mempunyai distribusi normal. Semua indikator dari variabel dukungan kelompok mempunyai critical ratio (CR) skewness dan kurtosis yang lebih kecil dari ambang batas $\pm 2,58$ pada taraf signifikansi $1 \%$.

Untuk variabel keyakinan (belief), semua indikator mempunyai critical ratio (CR) skewness dan kurtosis yang lebih kecil dari ambang batas $\pm 2,58$ pada taraf signifikansi $1 \%$.
Dengan demikian, variabel keyakinan (belief) juga mempunyai distribusi normal. Variabel selective exposure juga memenuhi syarat sebagai data yang berdistribusi normal. Semua indikator yang dipakai mempunyai critical ratio (CR) skewness dan kurtosis yang lebih kecil dari ambang batas $\pm 2,58$ pada taraf signifikansi $1 \%$.

Untuk menguji model teoritik yang telah disusun dilakukan pengujian kecocokan model dengan data penelitian. Dari hasil uji kecocokan model diketahui bahwa model teoritik adalah model yang baik (fit model). Bahwa 17 ukuran kecocokan model memperlihatkan hasil yang baik. Beberapa ukuran penting, seperti RMSEA, AIC maupun NFI menunjukkan hasil ukuran permodelan yang baik. Hasil uji model kecocokan ini sudah dapat digunakan untuk menggambarkan model pengukuran dan model hubungan struktural antar variabel laten pada tabel 1 .

Pengujian model struktural dilakukan melalui pengukuran hubungan variabel laten terdiri dari keyakinan (belief), kegunaan informasi dan dukungan kelompok terhadap selective exposure. Keyakinan (belief) dipengaruhi oleh kegunaan informasi dan dukungan kelompok. Sementara itu, selective exposure dipengaruhi oleh kegunaan informasi, dukungan kelompok dan keyakinan (belief) Melalui analisis model struktural akan dilakukan evaluasi hubungan dan pengaruh masingmasing konstruk melalui estimasi standar dan nilai t.

Dari tabel 2 terdapat lima koefisien yang signifikan secara statistik. Dengan demikian lima hipotesis yang diuji dalam penelitian ini adalah signifikan secara statistik. Dengan kata lain, kelima hipotesis yang dibuat berdasarkan pemikiran dan penelitian para ahli sebelumnya ternyata terbukti signifikan secara statistik.

Hasil uji model struktural memperlihatkan bahwa hubungan antara kegunaan informasi dan selective exposure adalah signifikan, yang berarti hipotesa 1 terbukti. Terdapat pengaruh kegunaan informasi terhadap selective exposure. Semakin bermanfaat sebuah informasi maka akan semakin dipilih dan tidak dihindari, dan sebaliknya. Hasil dari koefisien jalur sebesar 1.97, dan nilai-t sebesar 8.06.

Berdasarkan hasil penelitian, dapat disimpulkan bahwa selective exposure dilakukan oleh individu untuk mencari manfaat 
Tabel 1 Ukuran Kecocokan Model

\begin{tabular}{|c|c|c|c|}
\hline Ukuran GOF & Target-Tingkat Kecocokan & $\begin{array}{l}\text { Hasil } \\
\text { Estimasi }\end{array}$ & $\begin{array}{l}\text { Tingkat } \\
\text { Kecocokan }\end{array}$ \\
\hline Chi-Square & Semakin kecil semakin baik & 47.13 & Relative \\
\hline Chi-Square / df & $\leq 2.0$ & $47.13 / 50$ & Good \\
\hline Probability ( $p$ value) & P-value $\geq 0.05$ & 0.9998 & Good \\
\hline NCP Interval & Semakin kecil semakin baik & 47.68 & Relative \\
\hline RMSEA & $\begin{array}{l}\text { RMSEA } \leq 0.08 \text { (goof fit) } \\
\text { RMSEA } \leq 0.05 \text { (close fit) }\end{array}$ & 0.013 & Good \\
\hline ECVI & Nilai model mendekati nilai saturated ECVI & 10.52 & Good \\
\hline AIC & Nilai model mendekati nilai saturated AIC & 48.00 & Good \\
\hline CAIC & Nilai model mendekati nilai saturated CAIC & 48.35 & Good \\
\hline NFI & $\begin{array}{l}\text { NFI } \geq 0.90 \text { (good fit }) \\
0.80 \leq \mathrm{NFI} \leq 0.90 \text { (marginal fit })\end{array}$ & 0.98 & Good \\
\hline NNFI & $\begin{array}{l}\text { NNFI } \geq 0.90(\text { good fit }) \\
0.80 \leq \mathrm{NNFI} \leq 0.90(\text { marginal fit })\end{array}$ & 0.98 & Good \\
\hline CFI & $\begin{array}{l}\mathrm{CFI} \geq 0.90(\text { good fit }) \\
0.80 \leq \mathrm{CFI} \leq 0.90(\text { marginal fit })\end{array}$ & 0.98 & Good \\
\hline IFI & $\begin{array}{l}\text { IFI } \geq 0.90 \text { (good fit }) \\
0.80 \leq \text { IFI } \leq 0.90 \text { (marginal fit })\end{array}$ & 0.98 & Good \\
\hline RFI & $\begin{array}{l}\text { RFI } \geq 0.90(\text { good fit }) \\
0.80 \leq \mathrm{RFI} \leq 0.90 \text { (marginal fit })\end{array}$ & 0.98 & Good \\
\hline $\mathrm{CN}$ & $\mathrm{CN} \geq 200$ & 7.02 & Good \\
\hline RMR & $\mathrm{RMR} \leq 0.05($ good fit $)$ & 0.019 & Good \\
\hline GFI & $\begin{array}{l}\text { GFI } \geq 0.90 \text { (good fit }) \\
0.80 \leq \mathrm{GFI} \leq 0.90 \text { (marginal fit })\end{array}$ & 0.99 & Good \\
\hline AGFI & $\begin{array}{l}\text { AGFI } \geq 0.90 \text { (good fit) } \\
0.80 \leq \text { AGFI } \leq 0.90 \text { (marginal fit) }\end{array}$ & 0.99 & Good \\
\hline
\end{tabular}

Sumber: Hasil Penelitian, 2019

dari sebuah informasi untuk kenyamanan diri. Ketika ada ketidaknyamanan atau ketidaksesuaian (inkonsistensi) dalam kognisi, yang merupakan ketegangan dari dua pikiran yang berlawanan, maka akan timbul disonansi. Untuk menghindari disonansi, maka individu akan memerhatikan manfaat dari informasi. Jadi informasi yang dipilih dan dihindari/ ditolak tidaklah harus informasi yang sesuai dengan sikap dan keyakinan (belief), tetapi juga informasi yang bertentangan asalkan informasi tersebut memiliki manfaat/kegunaan. Dengan kata lain, hanya informasi yang bermanfaat yang akan dipilih, sekalipun informasi tersebut disonan, dan sebaliknya. Sekalipun sebuah informasi konsonan, namun bila kurang memiliki manfaat maka informasi tersebut akan dihindari ataupun ditolak. Hasil penelitian ini juga memperkuat hasil penelitian Valentino yang menyatakan bahwa terdapat hubungan antara kegunaan informasi dengan kegelisahan/ disonansi (Valentino et al., 2009).

Dalam kasus pornografi, sejauh informasi tentang pornografi memiliki manfaat maka informasi termaksud akan dipilih. Manfaat terkait informasi tentang pornografi adalah untuk pemenuhan kebutuhan informasi mengenai seks dan kesehatan reproduksi. Hal ini dapat dimaklumi mengingat tingginya rasa ingin tahu yang memang merupakan ciri khas remaja membuat remaja sangat penasaran dengan perkembangan phisik yang terjadi atas 
Tabel 2 Model Struktural - Hubungan Antar Variabel

\begin{tabular}{lllllc}
\hline $\begin{array}{l}\text { Variabel Laten } \\
\text { Independen }\end{array}$ & & $\begin{array}{l}\text { Variabel Laten } \\
\text { Dependen }\end{array}$ & Parameter & $\begin{array}{l}\text { Estimasi } \\
\text { Standar }\end{array}$ & Nilai t \\
\hline $\begin{array}{l}\text { Kegunaan Informasi } \\
(\mathrm{X} 1)\end{array}$ & $\rightarrow$ & Keyakinan (Y1) & $\square 11$ & 0.76 & 6.86 \\
$\begin{array}{l}\text { Kegunaan Informasi } \\
(\mathrm{X} 1)\end{array}$ & $\rightarrow$ & Selective Exposure (Y2) & $\square 21$ & 1.97 & 8.06 \\
$\begin{array}{l}\begin{array}{l}\text { Dukungan Kelompok } \\
(\mathrm{X} 2)\end{array} \\
\begin{array}{l}\text { Dukungan Kelompok } \\
(\mathrm{X} 2)\end{array}\end{array}$ & $\rightarrow$ & Keyakinan (Y1) & $\square 12$ & 0.51 & 4.07 \\
Keyakinan (Y1) & $\rightarrow$ & Selective Exposure (Y2) & $\square 22$ & 1.28 & 5.98 \\
\hline
\end{tabular}

Sumber: Hasil Penelitian, 2019

diri mereka. Dengan kata lain, seleksi terhadap informasi tentang pornografi akan dilakukan berdasarkan tujuan tertentu (purposeful). Semakin informasi tentang pornografi dapat memenuhi tujuan semakin informasi akan dipilih, dan sebaliknya. Dalam hal ini, individu dipandang bisa menilai informasi yang berguna dan tidak berguna bagi dirinya, dan proses seleksi informasi karenanya dilihat sebagai upaya dengan tujuan tertentu berkaitan dengan kegunaan sebuah informasi.

Hasil uji model struktural memperlihatkan bahwa hubungan antara kegunaan informasi dan keyakinan (belief) adalah signifikan, yang berarti hipotesa 2 terbukti. Terdapat pengaruh kegunaan informasi terhadap keyakinan (belief). Semakin tinggi manfaat sebuah informasi maka akan semakin memperkuat keyakinan yang dimiliki, dan sebaliknya. Hasil dari koefisien jalur sebesar 0.76, dan nilai-t sebesar 6.86.

Berdasarkan hasil penelitian, dapat disimpulkan bahwa individu tidak akan menolak atau menghindar dari informasi disonan, sejauh informasi disonan bermanfaat untuk memberikan argumentasi atau sanggahan yang berguna untuk lebih meyakinkan keputusan, pendapat ataupun keyakinan (belief) yang dimiliki. Informasi disonan juga akan diperhatikan jika informasi tersebut bermanfaat untuk menambah pengetahuan, dan pemahaman lebih lanjut terkait suatu hal yang dipertentangkan. Sementara, informasi konsonan digunakan sebagai penguatan terhadap keyakinan yang dimiliki. Jika sebuah informasi konsonan dianggap tidak berkualitas, maka informasi tersebut tidak akan dipilih dan dihindari, karena akan melemahkan keyakinan (belief).

Dalam kasus pornografi, informasi tentang pornografi akan bermanfaat untuk lebih memperkuat keyakinan (belief) bahwa pornografi mengandung informasi yang bertentangan dengan norma-norma sosial (seperti kepantasan, kesopanan, kepercayaan dan lainnya). Sebaliknya, informasi yang menentang pornografi akan memperlemah keyakinan (belief) apabila informasi tersebut tidak bisa menyajikan data maupun fakta yang memperlihatkan bahwa pornografi itu berpotensi merusak moral generasi bangsa, khususnya remaja.

Hasil uji model struktural memperlihatkan hubungan antara keyakinan (belief) dan selective exposure adalah signifikan, yang berarti hipotesa 3 terbukti. Terdapat pengaruh keyakinan (belief) terhadap selective exposure. Semakin kuat keyakinan (belief) dimiliki maka akan semakin selektif pilihan informasi dilakukan berdasarkan keyakinan (belief), dan sebaliknya. Hasil ini terlihat dari koefisien jalur sebesar 1.31, dan nilai-t sebesar 3.03.

Hasil penelitian ini mendukung pemikiran awal Festingeryang menyatakan bahwa keyakinan (belief) merupakan variabel penyebab selective exposure. Dalam teori disonansi kognitif, Festinger menyatakan bahwa untuk mengatasi ketidaknyamanan psikologis dan mencapai keseimbangan kognitif, manusia 
senantiasa menjaga kemapanan dan konsistensi dalam kognitifnya. Dengan menerima informasi yang mendukung akan membuat orang merasa nyaman, dan sebaliknya menerima informasi yang bertentangan dengan keyakinan akan menyebabkan orang berada dalam kondisi disonan (Festinger, 1957).

Dalam kasus pornografi, manakala individu meyakini bahwa informasi tentang pornografi adalah hal yang bermanfaat menambah pengetahuan terkait perilaku seks maka informasi akan dipilih, dan sebaliknya. Keyakinan (belief) pada kasus pornografi lebih menekankan pada bahwa individu merasa yakin akan manfaat dari informasi pornografi.

Hasil uji model struktural memperlihatkan bahwa hubungan antara dukungan kelompok dan keyakinan (belief) adalah signifikan, yang berarti hipotesa 4 terbukti. Terdapat pengaruh dukungan kelompok terhadap keyakinan (belief). Semakin besar dukungan kelompok maka akan semakin memperkuat keyakinan (belief), dan sebaliknya. Hasil dari koefisien jalur sebesar 0.51, dan nilai t sebesar 4.07.

Hasil penelitian ini memperkuat sejumlah penelitian yang telah dilakukan oleh para ahli sebelumnya (Galdi et al., 2012; Hutagalung, 2018). Dalam bukunya "A Theory of Cognitive Disonance" Festinger juga menegaskan bahwa dukungan sosial (social support) merupakan sumber disonansi kognitif seseorang, dan sekaligus juga merupakan sarana utama untuk mengeliminasi serta menurunkan disonansi. Yaitu, bahwa individu akan merubah keyakinan (belief) manakala bertentangan dengan kelompok untuk mencapai keselarasan/ keseimbangan kognitif.

Pada penelitian selanjutnya, Knobloch menegaskan bahwa dukungan kelompok hanya akan berarti apabila kelompok sosial merupakan identitas utama, dimana sikap dan perilaku anggota kelompok menjadi referensi yang relevan bagi sikap dan perilaku individu yang mendapatkan dukungan. Yaitu, bahwa seseorang mendapatkan rasa identitas sosial (social identity) dari kelompok yang dikagumi dan dihubungkan dengan diri pribadi. Manakala keterikatan bathin individu sangat erat dengan kelompok, maka norma yang berlaku dalam kelompok akan menjadi dasar individu untuk berperilaku, dan sebaliknya (KnoblochWesterwick \& Hastall, 2010).

Berdasarkan hasil penelitian, dapat disimpulkan bahwa dukungan kelompok memiliki pengaruh yang bisa memperkuat atau memperlemah keyakinan (belief) seseorang. Yaitu, bila keyakinan (belief) seseorang mendapatkan dukungan kelompok maka hal ini akan semakin memperkuat keyakinan (belief) yang dimiliki. Adanya dukungan kelompok dapat bermakna bahwa keyakinan (belief) sesuai dan tidak bertentangan dengan norma kelompok. Sebaliknya, semakin kecil dukungan kelompok yang diterima maka akan melemahkan keyakinan (belief) yang dimiliki. Dan sebagai konsekwensi, orang akan mengubah keyakinannya untuk mencapai keseimbangan kognitif dengan kelompok dimana seseorang menjadi bagian/anggota. Dalam kasus pornografi, semakin kelompok tidak mendukung informasi tentang pornografi, seperti dikeluarkannya UU Pornografi nomor 44 tahun 2008, maka semakin menguatkan keyakinan (belief) bahwa pornografi memang harus ditolak dengan tegas. Dan sebaliknya, bila dukungan kelompok semakin menguat terhadap informasi tentang pornografi, maka semakin melemahkan keyakinan (belief) bahwa pornografi harus dihindari dan ditolak.

Hasil uji model struktural memperlihatkan bahwa hubungan antara dukungan kelompok dan selective exposure adalah signifikan, yang berarti hipotesa 5 terbukti. Terdapat pengaruh dukungan kelompok terhadap selective exposure. Semakin besar atau semakin kuat dukungan kelompok terhadap sebuah informasi maka informasi akan semakin dipilih, dan sebaliknya. Semakin kecil atau melemah dukungan kelompok terhadap sebuah informasi maka informasi akan semakin dihindari. Hasil dari koefisien jalur sebesar 1.28 , dan nilai-t sebesar 5.98 .

Hasil penelitian ini memperkuat penelitian yang membuktikan bahwa dukungan kelompok cenderung memengaruhi selective exposure (Ahn, 2010). Dalam konteks selective exposure dapat digambarkan bahwa seseorang lebih memilih informasi tertentu ketika dukungan kelompok menguat terhadap informasi. Misalnya, anggota kelompok banyak yang menonton suatu tayangan televisi, maka kondisi ini bisa membuat seseorang akan menonton tayangan film yang juga ditonton oleh anggota kelompoknya. Keanggotaan dalam kelompok menjadi pedoman penting bagi seseorang untuk bersikap dan berperilaku. 
Berdasarkan hasil penelitian, dapat disimpulkan bahwa terdapat pengaruh dukungan kelompok terhadap selective exposure. Orang akan memerhatikan dukungan kelompok terkait pilihan atau penolakan sebuah informasi. Informasi yang mendapatkan dukungan kelompok akan menjadi pilihan, sementara informasi yang kurang mendapatkan dukungan akan dihindari ataupun ditolak. Hal ini dilakukan karena orang berupaya mencapai keseimbangan kognisi dan keselarasan dengan lingkungan sosial, sebagai perwujudan mahluk sosial.

Dalam kasus pornografi, kedekatan remaja dengan peer-group sangatlah tinggi karena selain ikatan peer-group menggantikan ikatan keluarga, mereka juga merupakan sumber afeksi, simpati dan pengertian, saling berbagi pengalaman, sekaligus sebagai tempat remaja untuk mencapai otonomi dan independensi. Maka tak heran bila remaja mempunyai kecenderungan untuk mengadopsi informasi yang diterima dari teman, tanpa memiliki dasar informasi yang signifikan dari sumber yang lebih dapat dipercaya. Informasi dari teman, dalam hal ini terkait pornografi, tak jarang menimbulkan rasa penasaran yang membentuk serangkaian pertanyaan dalam diri remaja. Untuk menjawab pertanyaan itu sekaligus membuktikan kebenaran informasi yang diterima, remaja cenderung mengikuti kesepakatan peer-group. Jika peer-group bersepakat bahwa sebuah informasi pornografi memiliki manfaat maka individu akan ikut memilih informasi termaksud, dan sebaliknya (Hutagalung, 2016).

\section{SIMPULAN}

Penelitian ini didasarkan pada titik tolak bahwa penyebab selective exposure tidak bisa hanya dijelaskan oleh satu variabel saja, namun harus dijelaskan secara holistik (gabungan dari berbagai aspek). Titik tolak atau asumsi ini didasari pada hasil penelusuran penelitian para ahli sebelumnya yang telah membuktikan bahwa selective exposure bisa disebabkan oleh lebih dari satu variabel dari berbagai aspek. Berdasarkan titik tolak ini, peneliti melihat celah pemikiran untuk meneliti integrasi pengaruh variabel keyakinan (belief), kegunaan informasi dan dukungan kelompok terhadap selective exposure dalam satu model penelitian.
Dengan mengambil kasus pornografi, penelitian ini berupaya untuk menarik simpulan apakah integrasi variabel keyakinan (belief), kegunaan informasi dan dukungan kelompok terbukti memiliki pengaruh terhadap selective exposure. Pornografi diambil sebagai kasus penelitian didasari argumentasi bahwa pornografi merupakan salah satu masalah sosial di Indonesia dengan fenomena gunung es yang memerlukan perhatian serius. Adapun alasan pemilihan remaja sebagai responden penelitian dikarenakan remaja merupakan populasi terbesar yang menjadi sasaran pornografi.

Secara umum, hasil penelitian membuktikan bahwa selective exposure bisa disebabkan oleh integrasi pengaruh variabel keyakinan (belief), kegunaan informasi dan dukungan kelompok.

Komunikasi pada konteks pemilihan dan penolakan informasi tentang pornografi terbagi dalam tiga tingkatan. Pertama, tingkatan intrapersonal. Individu memiliki keyakinan (belief) yang akan menjadi jangkar untuk mengolah informasi. Kedua, tingkatan interpersonal ataupun kelompok. Sebagai mahluk sosial, individu akan bergaul dan memiliki kelompok yang dapat mempengaruhi proses pengolahan informasi. Ketiga, tingkatan komunikasi massa. Saat ini dengan kemajuan teknologi informasi individu akan melakukan seleksi informasi berdasarkan kegunaan informasi untuk pemenuhan kebutuhan informasi.

Di sisi lain, menyadari dampak pornografi yang dapat merusak masa depan generasi bangsa perlu dipertimbangkan oleh Kementerian Pendidikan dan Kebudayaan untuk pemberian materi kesehatan reproduksi pada kurikulum sekolah yang akan dapat menjadi sumber remaja untuk memperoleh informasi seksual. Hal ini disarankan agar keingintahuan remaja terhadap informasi seksual dapat dipenuhi. Sebagaimana dipahami makin meningkatnya jumlah remaja yang terpapar informasi pornografi tidak hanya berkontribusi terhadap meningkatnya jumlah remaja yang berperilaku seksual aktif, tetapi juga dengan semakin meningkatnya kasus kehamilan tidak dikehendaki (KTD), dan tindakan aborsi yang kerap dianggap sebagai sebuah solusi permasalahan KTD. Padahal, tindakan aborsi sangat berisiko tinggi terhadap kesehatan reproduksi yang dapat mengakibatkan infertilitas atau bahkan kematian. Pornografi juga berpotensi meningkatkan kejahatan 
seksual, termasuk masalah human traficking (penculikan manusia). Banyak kasus yang menimpa remaja menunjukkan bahwa mereka melakukan kejahatan seksual karena terangsang materi pornografi yang sering ditonton. Adapun human traficking merupakan imbas dari kebutuhan perempuan yang meningkat untuk melayani konsumen pornografi yang memerlukan pelampiasan melalui prostitusi.

\section{DAFTAR PUSTAKA}

Ahn, D. (2010). The appeal of tragic drama to lonely individuals: Selective exposure to media content.

Baran, S. J. (2012). Introduction to mass communication: Media literacy and culture (7th ed.). McGraw-Hill.

Bennett, W. L., \& Iyengar, S. (2008). A new era of minimal effects? The changing foundations of political communication. Journal of Communication, 58(4), 707-731. https:// doi.org/10.1111/j.1460-2466.2008.00410.x

Festinger, L. (1957). A theory of cognitive dissonance. In Scientific American (Vol. 207, p. 291). https://doi.org/10.1037/10318001

Fischer, P., \& Greitemeyer, T. (2010). Anew look at selective-exposure effects: An integrative model. Current Directions in Psychological Science, 19(6), 384-389. https://doi. org/10.1177/0963721410391246

Fischer, P., Kastenmüller, A., Greitemeyer, T., Fischer, J., Frey, D., \& Crelley, D. (2011). Threat and elective exposure: The moderating role of threat and decision context on confirmatory information search after decisions. Journal of Experimental Psychology, 140(1), 51-62. https://doi.org/ https://doi.org/10.1037/a0021595

Galdi, S., Bertran, G., Luciano, A., \& Mate, F. (2012). Selective exposure in decided and undecided individuals: Differential relations to automatic association and conscious beliefs. Personality and Social Psychology Bulletin, 38(5), 559-569. https://doi.org/https://doi. org/10.1177/0146167211435981

Griffin, E. (2011). A First Look At Communication Theory. McGraw-Hill.

Hutagalung, I. (2016). Pola pemikiran dan penolakan informasi pornografi di kalangan remaja. Journal Communication, 7(1), 36-46. https://doi.org/http://dx.doi. org/10.36080/comm.v7i1.75

Hutagalung, I. (2017). The utility of information in selective exposure of pornography among teenagers in Indonesia. International Journal of Social Relevance \& Concern, 5(5), 18-25.

Hutagalung, I. (2018). The influence of belief, utility of information, and group support on selective exposure to pornography among teenagers in Jakarta, Indonesia. International Journal of Engineering \& Technology, 7(2.29), 557-563. https://doi. org/10.14419/ijet.v7i2.29.13817

Kholisoh, N. (2018). Media literacy training for senior high school students in administrative village of Rawa Buaya in addressing pornographic content on youtube social media. Proceeding of International Conference on Community Development, 1(1), 200-205. https://doi. org/10.33068/iccd.vol1.iss1.31

Knobloch-Westerwick, S., \& Hastall, M. R. (2010). Please your self: Social identity effects on selective exposure to news about in-and out-groups. Journal of Communication, 60(3), 515-535. https:// doi.org/10.1111/j.1460-2466.2010.01495.x

Littlejohn, S., \& Foss, K. A. (2011). Theories of human communication. Thomson Wadsworth.

Silvia Knobloch-Westerwick, S. B. K. (2012). Preelection selective exposure: confirmation bias versus informational utility. Communication Research Journal, 39(2), 170-193. https://doi.org/https://doi. org/10.1177/0093650211400597

Stroud, N. J. (2008). Media use and political predispositions: revisiting the concept of selective exposure. Political Behavior, 30(3), 341-366. https://doi.org/10.1007/ s11109-007-9050-9

Valentino, N. A., Banks, A. J., Hutchings, V. L., \& Davis, A. K. (2009). Selective exposure in the internet age: The interaction between anxiety and information utility. Political Psychology, 30(4), 591-613. https://doi. org/10.1111/j.1467-9221.2009.00716.x

Zillmann, D., \& Bryant, J. (1985). Selective exposure to communication. Routledge. 